\title{
ANALISIS LOGAM BERAT DALAM DAUN SIRSAK DAN DAUN BELUNTAS
}

\author{
Sabaniah Indjar Gama \\ Laboratorium Kimia Farmasi Dasar Fakultas Farmasi Universitas Mulawarman \\ Corresponding author email : sndjargama@yahoo.com
}

\begin{abstract}
The Research about heavy metal that is contained in Medicine herbs has been. The soursop leaves and beluntas leaves has been analyzed metal content by atomic absorption spectrophotometer. The Results show that the concentration of $\mathrm{Pb}$ is $0392 \mathrm{ppm}$ in soursop leaves and 0,026 ppm in beluntas leaves. The concentrations of $\mathrm{Cd}$ metal is 0,0263 in soursop leaves and $0.0523 \mathrm{ppm}$ in beluntas leaves. it can be concluded that heavy metals $\mathrm{Pb}$ and $\mathrm{Cd}$ in some medicin herbs do not exceed the maximum limit of the $\mathrm{Pb}$ $<10$ ppm Cd<0.30 ppm.
\end{abstract}

Keywords ; Heavy metal Pb, Cd in medicine herbs.

\section{ABSTRAK}

Telah dilakukan penelitian mengenai logam berat yang terkandung dalam beberapa Tumbuhan Obat. Daun sirsak dan Daun beluntas, telah dianalisis kadar logam menggunakan metode spektrofotometer serapan atom. Hasil analisis menunjukan bahwa konsentarsi logam $\mathrm{Pb}$ pada daun sirsak 0.392 ppm, pada daun beluntas 0.026 ppm sedangkan konsentrasi logam Cd pada daun sirsak 0.0263 ppm dan daun beluntas 0.0523 ppm. Dapat disimpulkan bahwa Logam berat $\mathrm{Pb}$ dan $\mathrm{Cd}$ dalam beberapa tumbuhan obat tidak melebihi batas maksimal yakni $\mathrm{Pb}<10 \mathrm{ppm}$ dan $\mathrm{Cd}<0,30 \mathrm{ppm}$.

Kata kunci : Logam Berat $\mathrm{Pb}$ dan $\mathrm{Cd}$ Dalam Tumbuhan Obat

Submitted on: 4 April 2017

Accepted on: 5 July 2017

DOI: https://doi.org/10.25026/jsk.v1i8.82

\section{LATAR BELAKANG}

Pencarian tanaman untuk mengantikan obat sintesis telah banyak dilakukan, dengan tujuan menggurangi resistensi dari obat-obatan sintetik,dengan menggunakan obat herbal yang berasal dari tumbuhan yang memiliki kandungan metabolit sekunder dan primer yang terbukti memiliki aktifitas sebagai antikanker, antioksidan, antiinflamasi, antipiretik dan masih banyak khasiat lainya.

Beberapa hal yang perlu dikhawatirkan ketika kita mengunakan tanaman tersebut sebagai obat alami, yakni terkandungnya logam berat pada tanaman yang kita konsumsi baik karna terpapar maupun secara alami terkandung pada tanaman sebagai akibat dari tempat pertumbuhan tanaman tersebut . Logam berat adalah unsur logam yang mempunyai densitas $>5 \mathrm{~g} / \mathrm{cm}^{3}$. Logam berat masih termasuk golongan logam dengan kriteria-kriteria yang sama dengan logam-logam lain. Logam berat ada 2 yakni mikronutrien dan makronutrien yang memiliki fungsi didalam tubuh tergantung pada bagian mana dari logam berat tersebut yang terikat dalam tubuh, logam berat tersebut dapat menimbulkan efek gangguan terhadap kesehatan manusia, tergantung batas toleransi jika terpapar logam tersebut. 


\section{METODE}

\section{Alat dan Bahan}

Alat yang digunakan adalah timbangan analitik, oven, gelas kimia 100 $\mathrm{mL}$, Hote plate, labu takar $100 \mathrm{~mL}, 25$ $\mathrm{mL}, 250 \mathrm{~mL}$, sendok tanduk proselin, saringan mess diameter $100 \mu \mathrm{m}$, kertas saring Whatman No. 42, Instrument AAS, mortar dan lumpang

Bahan yang digunakan, $\mathrm{PbNO}_{3}$, $\mathrm{Cd}\left(\mathrm{NO}_{3}\right)_{2}, \mathrm{Cr}\left(\mathrm{NO}_{3}\right)_{3}, \mathrm{HNO}_{3}$, daun sirsak dan daun beluntas, aquadest, aquabidest.

\section{Prosedur Kerja}

Daun sirsak dan daun beluntas, disortasi kemudian dicuci dengan air mengalir, kemudian daun tersebut yang telah kering ditimbang di keringkan menggunakan oven dengan suhu $90^{\circ} \mathrm{C}$, kemudian digerus menggunakan mortar dan lumping hingga sampel tersebut ukuran partikelnya menjadi kecil.sampai di peroleh berat yang konstan (bobot yang tetap), Selanjutnya disaring menggunakan saringan mess dengan diameter $100 \mu \mathrm{m}$. Sebanyak 2 gram sampel daun sirsak dan daun beluntas, kemudian didestruksi dengan penambahan asam, setelah dingin kemudian disaring dengan kertas saring whatman 42. Filtrat sampel yang di peroleh dimasukkan ke dalam labu ukur/ takar $100 \mathrm{~mL}$ dan dicukupkan dengan aquabidest hingga tanda batas. Setelah itu, dikocok hingga homogen. kemudian dianalisis logam $\mathrm{Pb}, \mathrm{Cd}$ dengan menggunakan AAS (Adriani, 2012).

\section{HASIL DAN PEMBAHASAN}

Tanaman membutuhkan logam mineral untuk pertumbuhannya, yakni digunakan untuk respirasi, pembentukan piqmen atau zat hijau daun, sebagai kofaktor dan masih banyak lagi, akan tetapi ada beberapa logam berat yang keberadaannya didalam tubuh, fungsinya belum diketahui. Sehingga dalam jumlah kecilpun dapat membahayakan tubuh kita, contohnya adalah logam $\mathrm{Pb}$ dan logam Cd.

Tujuan dilakukan analisis logam berat pada tumbuhan obat, yakni daun beluntas dan daun sirsak untuk mengetahui berapa kandungan logam berat yang terdapat dalam tumbuhan obat tersebut, dimana kita ketahui banyak pengobatan tradisional yang menggunakan tumbuhan obat tersebut untuk menyembuhkan penyakit mulai dalam bentuk serbuk (simplesia), rebusan (infus) maupun sediaan jamu yang samasama kita ketahui bahwa pada tanaman obat tersebut menggandung logam berat.

Berdasarkan literatur bahwa logam berat mudah larut dengan air, dan pemanasan, lepasnya logam berat tersebut dari pengkelat pada tanaman dengan pemanasan yang cukup tinggi, sehingga penelusuran logam berat harus dilakukan dengan alasan keamanan untuk dikonsumsi.

Konsentrasi logam $\mathrm{Pb}$ dan $\mathrm{Cd}$ pada daun beluntas (Pluchea Indica L) dan daun sirsak (Annona muricata) dapat ditentukan dengan analisis logam menggunakan AAS (Atomic Absorption Spectrometer) dimana sampel berada dalam bentuk larutan. Kadar/konsentrasi logam Timbal pada daun beluntas dan daun sirsak adalah $0.392 \mathrm{mg} / \mathrm{L}$ dan 0.026 $\mathrm{mg} / \mathrm{L}$, dapat dilihat pada gambar 3.1. Logam timbal $(\mathrm{Pb})$ memiliki nomor atom 82 dengan konfigurasi elektron [Xe] $4 \mathrm{f}^{14} 5 \mathrm{~d}^{10} 6 \mathrm{~s}^{2} 6 \mathrm{p}^{2}$, logam timbal terdapat secara alami dalam kerak bumi akan tetapi timbal juga bisa berasal dari kegiatan manusia yakni penggunaannya dalam bidang industri seperti pembuatan kabel, bahan peledak,pewarnaan cat, pembangkit tenaga listrik, tenaga panas, bahan aditif pada bahan kendaran bermotor. 


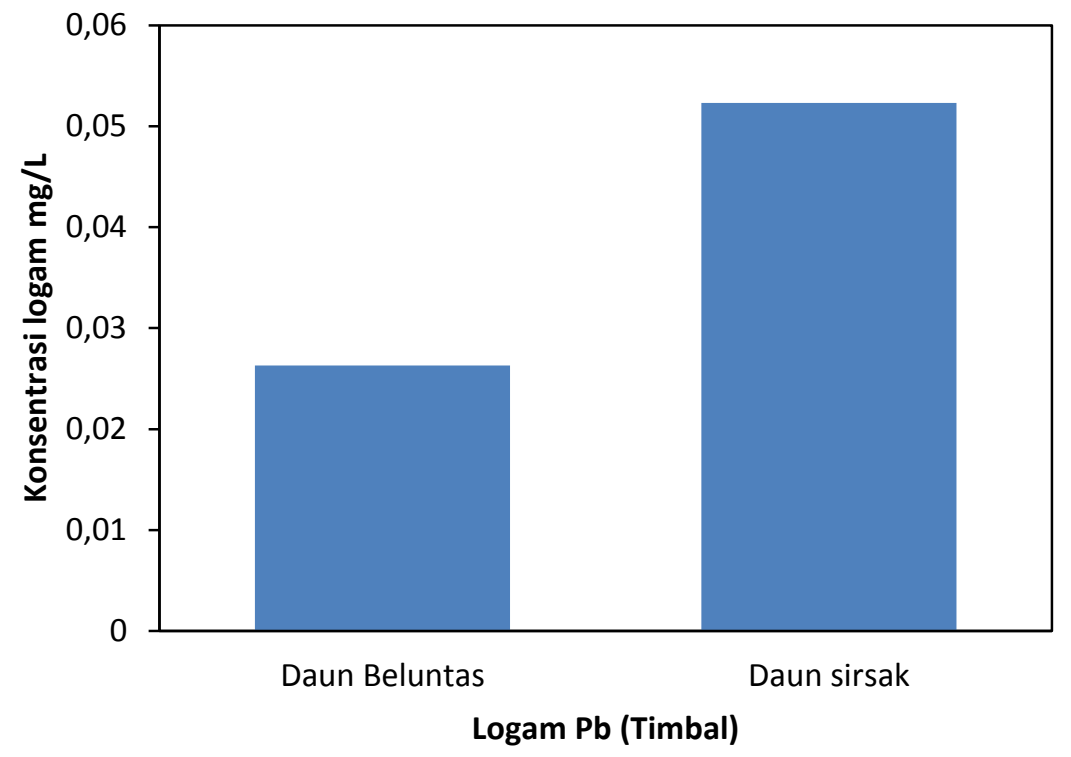

Gambar 1 Konsentrasi Logam Pb

Mekanisme keberadaan timbal
didalam tubuh, melalui saluran
pencernaan dan saluran pernafasan, jika
seorang mengkonsumsi sesuatu yang
mengandung timbal (Pb) secara oral
maka,timbal tersebut terakumulasi di
lambung sehingga akan menyebabkan
akumulasi senyawa $\mathrm{Pb}$ pada lambung.
Hal ini dapat terjadi karena akumulasi
senyawa $\mathrm{Pb}$ lebih tinggi jika
dibandingkan dengan ekskresinya (Rofiqoh 2013). Senyawa $\mathrm{Pb}$ yang terakumulasi di lambung, akan mengganggu keseimbangan antara faktor offensif dan faktor defensif. Dengan terakumulasinya senyawa $\mathrm{Pb}$ pada lambung, faktor-faktor offensif seperti asam $(\mathrm{HCl})$, NO (Nitric oxide), pepsin, Reactive Oxsigen Species (ROS), dan Helicobacter pylori akan meningkat akibat adanya $\mathrm{Pb}$ yang berlebih dalam tubuh dapat menyebabkan terjadinya pengikatan selenium, akibatnya aktivitas enzim GPx menurun (Ercal et al. 2001), sehingga Peningkatan radikal bebas yang melebihi normal, menyebabkan berkurangnya antioksidan yang berfungsi untuk menetralisir reactive oxygen species (ROS), sehingga kadar total status antioksidan (TSA) dalam tubuh mengalami penurunan. Bila radikal bebas lebih tinggi daripada antioksidan maka terjadi ketidakstabilan oksidatif yang disebut stres oksidatif, Sehingga efek samping yang dihasilkan pada penggunaan timbal secara oral maupun terpapar dapat menyebabkan kematian (toksisitas).

Kerusakan yang diakibatkan oleh timbal tidak hanya pada lambung, hati dan ginjal melainkan mengganggu kemampuan darah untuk membentuk hemoglobin (Ardiyanto 2005).

Logam kadmium (Cd) memiliki nomor atom 48, dengan konfigurasi elektron $[\mathrm{Kr}] 4 \mathrm{~d}^{10} 5 \mathrm{~s}^{2}$ logam kadmium terdapat dialam yakni dalam kerak bumi sedangkan dilingkungan, kadmium berasal dari emisi (pembuangan) industri, makanan yang tumbuh pada daerah yang tercemar pestisida, rokok, pupuk serta cat, keramik berglazur. Kadar/konsentrasi logam kadmium pada daun beluntas dan daun sirsak adalah $0.0263 \mathrm{mg} / \mathrm{L}$ dan $0.0523 \mathrm{mg} / \mathrm{L}$, dapat dilihat pada gambar 2 


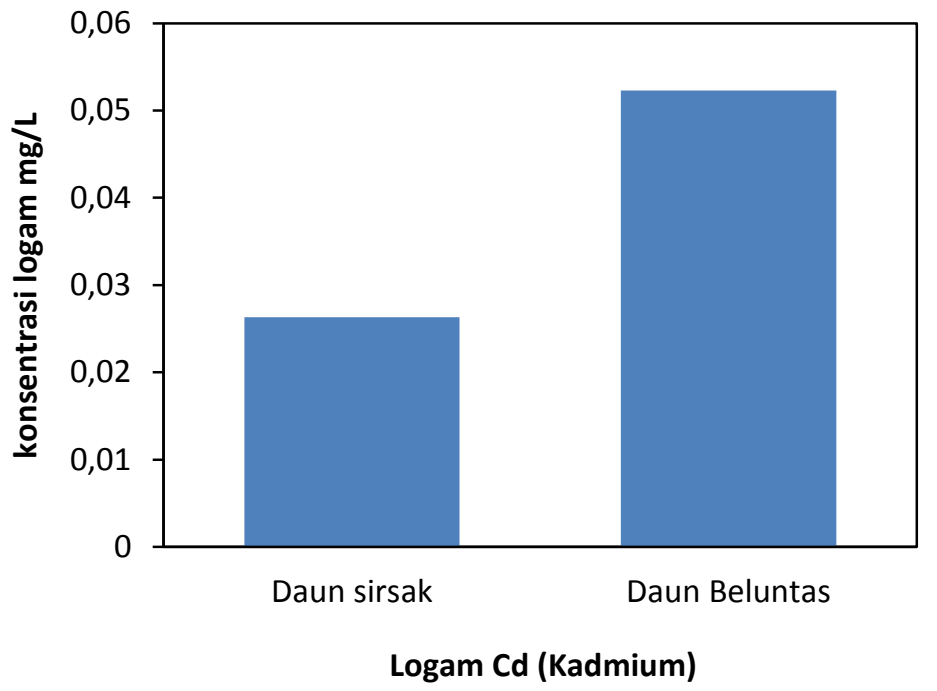

Gambar 2. Kadar logam Kadmium

Logam kadmium dapat masuk ke dalam tubuh manusia melalui saluran pencernaan dan pernafasan. Setelah itu,jika kadmium masuk melalui saluran pencernaan, yang teradsorbsi sangat sedikit dari total $\mathrm{Cd}$ yang dimasukan secara oral. Dalam usus kadmium menempel pada dinding sel sehingga diduga sel epitel usus mengatur absorbsi kadmium. bila konsentrasi kadmium yang menempel pada dinding tinggi maka akan merusak usus dan mengganggu transportasi kadmium pada protein, kalsium, besi dan seng dan meningkatkan daya toksisitas logam kadmium. Jika kadmium masuk kedalam tubuh melalui pernafasan, adsorpsi kadmium pada pernafasan lebih besar terutama pada paru-paru. Setelah Cd diabsorbsi dalam tubuh kemudian didistrbusikan oleh darah keberbagai jaringan terutama terakumulasi dalam hati dan ginjal. kadmium akan mengalami akumulasi di dalam organ terutama di dalam hati. Akumulasi kadmium di dalam hati akan memicu terjadinya kerusakan pada hati.

Mekanisme masuknya logam kadmium adalah kadmium masuk ke dalam tubuh, yang selanjutnya akan diubah dari senyawa lipofilik menjadi hidrofilik, agar dapat diekskresi. Secara umum, kadmium akan dimetabolisme dengan melibatkan sitokrom P450 di mitokondria, yang menghasilkan SOR. Pada sisi lain, kadmium juga akan mengalami biotransformasi melalui pengikatan glutation, yakni kofaktor glutation-Stransferase (GST). Glutation akan mengikat kadmium secara kovalen melalui gugus SH yang dimiliki glutation. Hal ini berakibat pada inaktivasi enzim GST, sehingga terjadi penumpukan senyawa $\mathrm{H}_{2} \mathrm{O}_{2}$, yakni oksidan kuat yang bersifat stabil.

Peningkatan penggunaan oksigen ini selanjutnya akan memicu aktivasi dari NADPH oksidase, sehingga dihasilkannya SOR seperti radikal superoksida dan $\mathrm{H}_{2} \mathrm{O}_{2}$ (Ciz et al, 2012). Paparan $\mathrm{Cd}$ dapat mengaktivasi sel fagositik seperti neutrofil untuk melakukan respiratory burst. Hal ini juga menyebabkan aktifnya enzim NADPH oksidase yang selanjutnya akan meningkatkan pembentukan senyawa $\mathrm{H}_{2} \mathrm{O}_{2}$.

Berdasarkan pernyataan diatas bahwa kadmium dan timbal dapat memicu pembentukan SOR dan SOD jika 
dalam jumlah yang berlebih. SOR dan SOD merupakan senyawa radikal yang terbentuk karena jika jumlah kadmium dan timbal jumlahnya berlebih.

\section{KESIMPULAN DAN SARAN}

a. Kadmium dan Timbal dapat memicu pembentukan SOR dan SOD jika dalam jumlah yang berlebih

b. Logam berat timbal dan kadmium dalam daun sirsak dan daun bluntas tidak melebihi batas maksimal yakni $\mathrm{Pb}<10 \mathrm{ppm}$ dan $\mathrm{Cd}<0,30$ ppm

c. Disarankan ketika mengunakan tumbuhan obat,sebagai pengganti obat sintetik untuk tidak langsung meyeduh simplisia tumbuhan tersebut melainkan harus dikemas dalam Kertas Filter setelah itu diseduh.

d. Perlunya dilakukan standarisasi terhadap tumbuhan obat yang terkandung dalam daun sirsak dan daun beluntas untuk dijadikan sediaan fitofarmaka.

\section{UCAPAN TERIMAKASIH}

Terima kasih kepada pihak-pihak yang berkontribusi terhadap penelitian ini terutama Dekan Fakultas Farmasi atas sumbangsih dana penelitian kepada saya.

\section{DAFTAR PUSTAKA.}

[1]. Darmano. 1995. Logam dalam system biologiMakhluk Hidup. Universitas Indonesia : Jakarta

[2]. Ciz M., Denev P., Kratchanova M., Vasicek O., Ambrozova G., Lojek A. (2012). Flavonoids inhibit the respiratory burst of neutrophils in mammals. Oxidative Medicine and Cellular Longevity. 2012 (181295): 1-6.

[3]. Rofiqoh N \& Taufikurohmah T. 2013. Pengaruh infiltrasi nanogold terhadap peningkatan kualitas jaringan dan kuantitas merkuri pada lambung mencit (Mus musculus) setelah terpapar merkuri. Journal of Chemistry 2(3): 24-33.

[4]. Rahmat El Aziz, Aditya miranti. 2014. Efek paparan kronik timbal (pb) per oral pada struktur histopatologik lambung tikus putih. Unnes J Life Sci 3 (2).

[5]. Siti Juliati. 2016. Pengaruh pajanan logam kadmium (cd) terhadap kadar peroksida (h2o2), kadar malodialdehid (mda) dan kadar metil glioksal (mg) pada hati tikus putih (rattus novergicus) EnviroScienteae Vol. 12 No. 1, 43-49.

[6]. Tahril. 2011. Analisis Besi dalam Ekosistem Lamun dan Hubungannya dengan Sifat Fisikokimia Perairan Pantai Kabupaten Donggala. Jurnal Natur Indonesia 13(2), 105111

[7]. Wahyu widowati, dkk. 2008. Efek Toksisitas Logam. Andi Yogyakarta : Bandung 